\title{
RELIABILITY OF THE SPECIFIC GRAVITY (SG) VALUE OF THREE INDONESIAN HARDWOODS USING EXPERIMENTAL TEST AND MONTE CARLO SIMULATION
}

\author{
Yosafat Aji Pranata, Pricillia Sofyan Tanuwijaya \\ Department of Civil Engineering, Maranatha Christian University \\ Jl. Suria Sumantri 65, Bandung, 40164, West Java - Indonesia \\ e-mail : yosafat.ap@eng.maranatha.edu
}

\begin{abstract}
ABSTRAK
Dalam perencanaan struktur dan properti material terdapat parameter-parameter dengan sifat ketidakpastian. Sebagai contoh adalah properti material, beban, dan kapasistas pembebanan suatu elemen struktur adalah bukan suatu kuantitas deterministic atau tidak secara tepat diketahui besarnya, melainkan merupakan nilai prediksi atau variabel acak. Sebagai contoh modulus elastisitas material kayu daun lebar, berat jenis, rasio poisson, dan lain-lain. Konsekuensinya, struktur harus didesain dengan metode probabilitas hingga terhadap kegagalan. Metode Monte Carlo merupakan suatu teknik spesial yang dapat digunakan untuk membangkitkan beberapa hasil numerik tanpa secara aktual melakukan tes fisik. Data dari hasil uji eksperimental sebelumnya dapat dimanfaatkan untuk digunakan untuk mendapatkan parameter-parameter penting. Ruang lingkup penelitian ini adalah melakukan uji eksperimental dengan benda uji tiga jenis kayu jenis daun lebar, yaitu: mersawa (anisoptera spp.), nyatoh (palaquium spp.), dan durian (durio spp.) dengan instrument Universal Testing Machine, dan melalkukan simulasi numeric (monte carlo) menggunakan perangkat lunak mandiri, yang dikembangkan dengan bahasa pemrograman VisualBasic. Tujuan simulasi monte carlo simulation adalah untuk memprediksi keandalan persamaan modulus elastisitas (SG). Jumlah benda uji seluruhnya sebanyak 48 benda uji. Parameter yang ditinjau dalam simulasi monte carlo adalah luas (panjang, lebar, dan tebal), berat pada kondisi basah, berat kering, kadar air, dan berat jenis. Hasil penelitian mengindikasikan bahwa perbedaan antara hasil uji eksperimental terhadap simulasi monte carlo simulation adalah sebesar $12.93 \%$. secara umum, hasil penelitian memperlihatkan bahwa simulasi Monte Carlo rasional digunakan untuk memprediksi keandalan persamaan berat jenis kayu jenis daun lebar.
\end{abstract}

Kata kunci: Berat jenis, Hardwood, Keandalan, Uji eksperimental, Simulasi Monte Carlo.

\begin{abstract}
Many sources of uncertainty are inherent in structural design and material properties. Despite what we often think, the parameters of the material properties, loading, and the load-carrying capacities of structural members are not deterministic quantities or they are not perfectly known. But they are "the predicted values" or random variables. For example, modulus of elasticity of hardwood material, specific grafity, poisson ratio and many more. Consequently, structures must be designed to serve their function with a finite probability of failure. The Monte Carlo method is a special technique that we can use to generate some results numerically without actually doing any physical testing. We can use results of previous tests to establish the probability distributions of the important parameters in our problem. Then we use this distribution information to generate samples of numerical data. The scope of this research are doing an experimental testing of three Indonesian hardwoods: mersawa (anisoptera spp.), nyatoh (palaquium spp.), and durian (durio spp.) using Universal Testing Machine instrument, and doing numerical simulation (monte carlo technique) using self-developed software, which was developed using VisualBasic programming language. The aim of the monte carlo simulation is to predict and verify the reliability of the specific gravity (SG). Total samples that used for experimental testing are 48 samples. The parameters which are considered for monte carlo simulation are area dimensions (length, width, and thickness), green weight, dry weight, moisture content, and specific gravity. Results indicated that relative difference between experimental test results and monte carlo
\end{abstract}


simulation are less than $12.93 \%$. For overalls, results in this research indicate that Monte Carlo simulation technique is reasonable used to predict the reliability of the specific gravity of hardwood.

Keywords: Specific Gravity, Hardwood, Reliability, Experimental test, Monte Carlo simulation.

\section{INTRODUCTION}

Many sources of uncertainty are inherent in structural design and material properties. Despite what we often think, the parameters of the material properties, loading, and the loadcarrying capacities of structural members are not deterministic quantities or they are not perfectly known. But they are "the predicted values" or random variables. For example, modulus of elasticity of hardwood material, specific grafity, poisson ratio and many more. Consequently, structures must be designed to serve their function with a finite probability of failure. The Monte Carlo method is a special technique that we can use to generate some results numerically without actually doing any physical testing. We can use results of previous tests to establish the probability distributions of the important parameters in our problem. Then we use this distribution information to generate samples of numerical data.

The scope of this research are doing an experimental testing of three Indonesian hardwoods: mersawa (anisoptera spp.), nyatoh (palaquium spp.), and durian (durio spp.) using Universal Testing Machine instrument, and doing numerical simulation (monte carlo technique) using self-developed software, which was developed using VisualBasic programming language. The aim of the monte carlo simulation is to predict and verify the reliability of the specific gravity (SG). Total samples that used for experimental testing are 48 samples. The parameters which are considered for monte carlo simulation are area dimensions (length, width, and thickness), green weight, dry weight, moisture content, and specific gravity.

\section{BASIC THEORY}

Wood may be described as an orthotropic material; that is, it has unique and independent mechanical properties in the directions of three mutually perpendicular axes: longitudinal, radial, and tangential. The longitudinal axis $L$ is parallel to the fiber (grain); the radial axis $R$ is normal to the growth rings (perpendicular to the grain in the radial direction); and the tangential axis $T$ is perpendicular to the grain but tangent to the growth rings [FPL, 1999]. Twelve constants (nine are independent) are needed to describe the elastic behavior of wood: three moduli of elasticity $E$, three moduli of rigidity $G$, and six Poisson's ratios $\mu$. The moduli of elasticity and Poisson's ratios are related by expressions of the equation 1 . 


$$
\frac{\mu_{i j}}{E_{i}}=\frac{\mu_{i j}}{E_{i}}, \quad i \neq j \quad i, j=L, R, T
$$

General relations between stress and strain for a homogeneous orthotropic material can be found in texts on anisotropic elasticity.

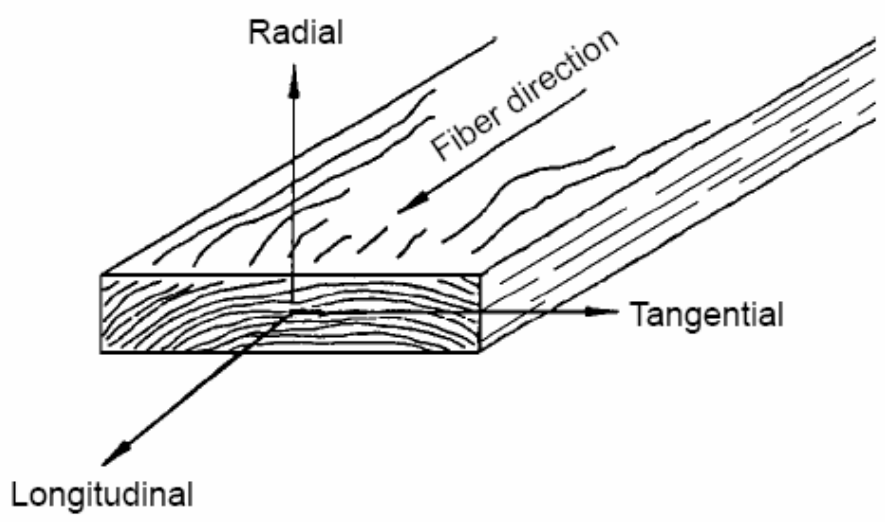

Figure 1. Three principal axes of wood with respect to grain direction and growth rings [FPL, 1999].

Elasticity implies that deformations produced by low stress are completely recoverable after loads are removed. When loaded to higher stress levels, plastic deformation or failure occurs. The three moduli of elasticity, which are denoted by $E_{L}, E_{R}$, and $E_{T}$, respectively, are the elastic moduli along the longitudinal, radial, and tangential axes of wood. These moduli are usually obtained from compression tests; however, data for $E_{R}$ and $E_{T}$ are not extensive. Average values of $E_{R}$ and $E_{T}$ for samples from a few species are presented in Wood Handbook Table 4-1 [FPL, 1999] as ratios with $E_{L}$; the Poisson's ratios are shown in Wood Handbook Table 4-2 [FPL, 1999]. The elastic ratios, as well as the elastic constants themselves, vary within and between species and with moisture content and specific gravity.

When a member is loaded axially, the deformation perpendicular to the direction of the load is proportional to the deformation parallel to the direction of the load. The ratio of the transverse to axial strain is called Poisson's ratio. The Poisson's ratios are denoted by $\mu_{L R}, \mu_{R L}, \mu_{L T}, \mu_{T L}, \mu_{R T}$, and $\mu_{T R}$. The first letter of the subscript refers to direction of applied stress and the second letter to direction of lateral deformation. For example, $\mu_{L R}$ is the Poisson's ratio for deformation along the radial axis caused by stress along the longitudinal axis. Average values of Poisson's ratios for samples of a few species are given in Wood 
Handbook Table 4-2 [FPL, 1999]. Values for $\mu_{R L}$ and $\mu_{T L}$ are less precisely determined than are those for the other Poisson's ratios. Poisson's ratios vary within and between species and are affected by moisture content and specific gravity.

The modulus of rigidity, also called shear modulus, indicates the resistance to deflection of a member caused by shear stresses. The three moduli of rigidity denoted by $G_{L R}, G_{L T}$, and $G_{R T}$ are the elastic constants in the $L_{R}, L_{T}$, and $R_{T}$ planes, respectively. For example, $G_{L R}$ is the modulus of rigidity based on shear strain in the $L_{R}$ plane and shear stresses in the $L_{T}$ and $R_{T}$ planes. Average values of shear moduli for samples of a few species expressed as ratios with $E_{L}$ are given in Wood Handbook Table 4-1 [FPL, 1999]. As with moduli of elasticity, the moduli of rigidity vary within and between species and with moisture content and specific gravity.

\subsection{Specific Gravity}

Specific gravity is based on weight when ovendry and volume when green or at $12 \%$ moisture content. Specific gravity is reported in many tables [FPL, 1999] because this property is used as an index of clear wood mechanical properties. The specific gravity values represent the estimated average clear wood specific gravity of the species. In the other tables, the specific gravity values represent only the specimens tested. The variability of specific gravity, represented by the coefficient of variation derived from tests on 50 species.

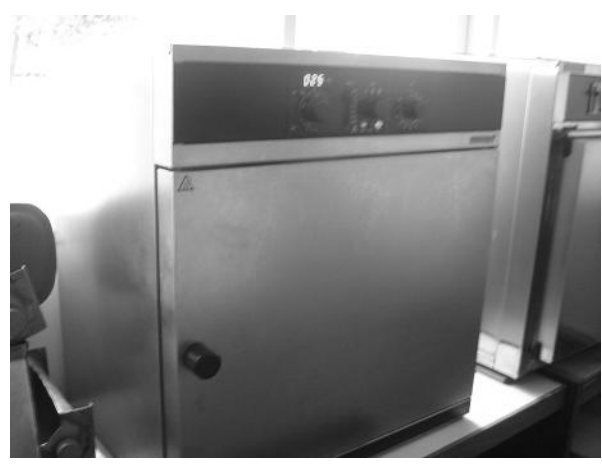

(a). Oven

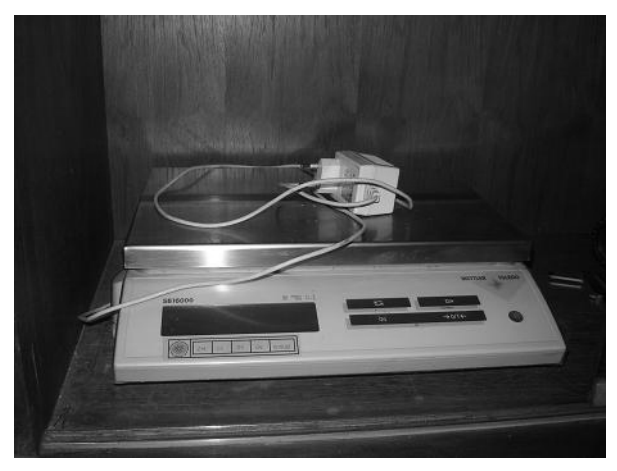

(b). Instrument.

Figure 2. Specific Gravity Instrument.

Clear straight-grained wood is used for determining fundamental mechanical properties; however, because of natural growth characteristics of trees, wood products vary in specific gravity, may contain cross grain, or may have knots and localized slope of grain. Natural defects such as pitch pockets may occur as a result of biological or climatic elements 
influencing the living tree. These wood characteristics must be taken into account in assessing actual properties or estimating the actual performance of wood products.

$$
\begin{aligned}
& S G=\frac{W_{\text {dry }}}{V} \\
& M C=\frac{W_{\text {wet }}-W_{\text {dry }}}{W_{d r y}} .100 \%
\end{aligned}
$$

where: $\mathrm{S} G \quad=$ specific gravity

$$
\begin{array}{ll}
W_{\text {kering }} & =\text { dry weight } \\
V & =\text { volume } \\
M C & =\text { moisture content } \\
W_{\text {basah }} & =\text { wet weight }
\end{array}
$$

The substance of which wood is composed is actually heavier than water; its specific gravity is about 1.5 regardless of wood species. In spite of this, the dry wood of most species floats in water, and it is thus evident that part of the volume of a piece of wood is occupied by cell cavities and pores. Variations in the size of these openings and in the thickness of the cell walls cause some species to have more wood substance per unit volume than other species and therefore higher specific gravity. Thus, specific gravity is an excellent index of the amount of wood substance contained in a piece of wood; it is a good index of mechanical properties as long as the wood is clear, straight grained, and free from defects.

However, specific gravity values also reflect the presence of gums, resins, and extractives, which contribute little to mechanical properties. Approximate relationships between various mechanical properties and specific gravity for clear straight-grained wood of hardwoods and softwoods as power functions. Those relationships are based on average values for the 43 softwood and 66 hardwood species [FPL, 1999]. The average data vary around the relationships, so that the relationships do not accurately predict individual average species values or an individual specimen value. In fact, mechanical properties within a species tend to be linearly, rather than curvilinearly, related to specific gravity; where data are available for individual species, linear analysis is suggested.

\subsection{Monte Carlo Simulation}

Monte Carlo methods are a widely used class of computational algorithms for simulating the behavior of various physical and mathematical systems. They are distinguished from other simulation methods (such as molecular dynamics) by being stochastic, that is nondeterministic in some manner - usually by using random numbers (or, 
more often, pseudo-random numbers) as opposed to deterministic algorithms. Because of the repetition of algorithms and the large number of calculations involved, Monte Carlo is a method suited to calculation using a computer, utilizing many techniques of computer simulation. A Monte Carlo algorithm is a numerical Monte Carlo method used to find solutions to mathematical problems (which may have many variables) that cannot easily be solved, for example, by integral calculus, or other numerical methods. For many types of problems, its efficiency relative to other numerical methods increases as the dimension of the problem increases.

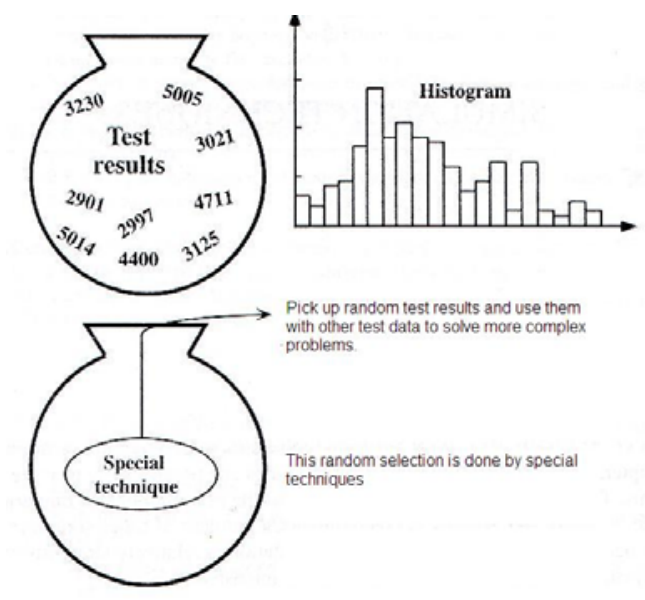

Figure 3. Monte Carlo Technique [Nowak, 2000].

The monte carlo method is a technique that we can use to generate some results numerically without actually doing any experimental tests. We can use results from previous tests to establish the probability distributions of the parameters in our problems. The we use this information to generate parameters of numerical data. However, in some instances, the problem being analyzed is extremely complex and the time needed to evaluate the problem for a single trial may be very long. As a result, the time needed to perform hundreds, thousands, or millions of simulations may be unfeasible.

Monte Carlo methods are especially useful in studying systems with a large number of coupled degrees of freedom, such as liquids, disordered materials, and strongly coupled solids [Wikipedia, 2008]. More broadly, Monte Carlo methods are useful for modeling phenomena with significant uncertainty in inputs, such as the calculation of risk in business. A classic use is for the evaluation of definite integrals, particularly multidimensional integrals with complicated boundary conditions. 
Monte Carlo methods are very important in computational physics and related applied fields, and have diverse applications from esoteric quantum chromodynamics calculations to designing heat shields and aerodynamic forms. Monte Carlo methods have also proven efficient in solving coupled integral differential equations of radiation fields and energy transport, and thus these methods have been used in global illumination computations which produce photorealistic images of virtual 3D models, with applications in video games, architecture, design, computer generated films, special effects in cinema, business, economics and other fields.

\section{CASE STUDY AND RESULTS}

Total samples that used for experimental testing are 48 samples. The parameters which are considered for monte carlo simulation are area dimensions (length, width, and thickness), green weight, dry weight, moisture content, and specific gravity. In this study, parameters such as $a, W, b, h, W_{d r y}$, and $S G$ will be used as random variables, that are normal, lognormal, and uniformly distributed. To get some level of accuration results, hence used 2000 data of random variables and experimental results.

Table 1. Moisture content and Specific gravity of Mersawa.

\begin{tabular}{|c|c|c|c|c|}
\hline Model & $\begin{array}{c}W_{\text {wet }} \\
(\mathrm{gr})\end{array}$ & $\begin{array}{c}W_{d r y} \\
(\mathrm{gr})\end{array}$ & $\begin{array}{c}\text { Moisture } \\
\text { content }(\%)\end{array}$ & $\begin{array}{c}\text { Specific Gravity } \\
\left(\mathrm{gr} / \mathrm{cm}^{3}\right)\end{array}$ \\
\hline MW01 & 111,0 & 98,0 & 13,27 & 0,5964 \\
\hline MW02 & 118,0 & 106,0 & 11,32 & 0,6760 \\
\hline MW03 & 105,0 & 94,0 & 11,70 & 0,5878 \\
\hline MW05 & 106,0 & 93,0 & 13,98 & 0,5564 \\
\hline MW06 & 109,0 & 96,0 & 13,54 & 0,5589 \\
\hline MW07 & 121,0 & 108,0 & 12,04 & 0,6755 \\
\hline MW08 & 106,0 & 94,0 & 12,77 & 0,5798 \\
\hline MW09 & 119,0 & 106,0 & 12,26 & 0,6888 \\
\hline MW10 & 122,0 & 109,0 & 11,93 & 0,6658 \\
\hline MW11 & 118,0 & 105,0 & 12,38 & 0,5858 \\
\hline MW12 & 110,0 & 97,0 & 13,40 & 0,5771 \\
\hline MW13 & 110,0 & 97,0 & 13,40 & 0,5843 \\
\hline MW14 & 118,0 & 104,0 & 13,46 & 0,5984 \\
\hline MW15 & 120,0 & 106,0 & 13,21 & 0,6119 \\
\hline MW16 & 114,0 & 101,0 & 12,87 & 0,5852 \\
\hline
\end{tabular}


Table 2. Moisture content and Specific gravity of Nyatoh.

\begin{tabular}{|c|c|c|c|c|}
\hline Model & $\begin{array}{c}W_{\text {wet }} \\
(g r)\end{array}$ & $\begin{array}{c}W_{d r y} \\
(g r)\end{array}$ & $\begin{array}{c}\text { Moisture } \\
\text { content (\%) }\end{array}$ & $\begin{array}{c}\text { Specific Gravity } \\
\left(\mathrm{gr} / \mathrm{cm}^{3}\right)\end{array}$ \\
\hline NY02 & 109,0 & 97,0 & 12,37 & 0,5707 \\
\hline NY03 & 120,0 & 107,0 & 12,15 & 0,6207 \\
\hline NY05 & 119,0 & 107,0 & 11,21 & 0,6230 \\
\hline NY06 & 105,0 & 94,0 & 11,70 & 0,5455 \\
\hline NY07 & 116,0 & 104,0 & 11,54 & 0,5782 \\
\hline NY08 & 114,0 & 102,0 & 11,76 & 0,5958 \\
\hline NY09 & 112,0 & 100,0 & 12,00 & 0,5719 \\
\hline NY10 & 116,0 & 104,0 & 11,54 & 0,5913 \\
\hline NY11 & 108,0 & 96,0 & 12,50 & 0,5571 \\
\hline NY12 & 113,0 & 101,0 & 11,88 & 0,5919 \\
\hline NY13 & 115,0 & 106,0 & 8,49 & 0,5994 \\
\hline NY14 & 116,0 & 104,0 & 11,54 & 0,5904 \\
\hline
\end{tabular}

Table 3. Moisture content and Specific gravity of Durian.

\begin{tabular}{|c|c|c|c|c|}
\hline Model & $\begin{array}{c}W_{\text {wet }} \\
(g r)\end{array}$ & $\begin{array}{c}W_{d r y} \\
(g r)\end{array}$ & $\begin{array}{c}\text { Moisture } \\
\text { content (\%) }\end{array}$ & $\begin{array}{c}\text { Specific Gravity } \\
\left(\mathrm{gr} / \mathrm{cm}^{3}\right)\end{array}$ \\
\hline DR01 & 102,0 & 90,0 & 13,33 & 0,5111 \\
\hline DR03 & 84,0 & 74,0 & 13,51 & 0,4293 \\
\hline DR07 & 98,0 & 86,0 & 13,95 & 0,5041 \\
\hline DR09 & 91,0 & 79,0 & 15,19 & 0,4545 \\
\hline DR10 & 94,0 & 83,0 & 13,25 & 0,4709 \\
\hline DR12 & 93,0 & 81,0 & 14,81 & 0,4658 \\
\hline DR13 & 92,0 & 81,0 & 13,58 & 0,4658 \\
\hline DR14 & 94,0 & 82,0 & 14,63 & 0,4831 \\
\hline DR15 & 92,0 & 81,0 & 13,58 & 0,4719 \\
\hline DR16 & 93,0 & 82,0 & 13,41 & 0,4897 \\
\hline DR17 & 91,0 & 80,0 & 13,75 & 0,4857 \\
\hline DR18 & 93,0 & 82,0 & 13,41 & 0,4739 \\
\hline
\end{tabular}

\subsection{Results}

In general, results for this study indicated that the difference relative of specific gravity $(S G)$ between monte carlo simulation method and experimental tests, giving results between $9.28 \%$ - 31.79\%.

Table 4. Results of simulation.

\begin{tabular}{|l|c|c|c|}
\hline \multirow{2}{*}{} & \multicolumn{3}{|c|}{ SG } \\
\cline { 2 - 4 } & simulasi & experimental & $\begin{array}{c}\%- \\
\text { relatif }\end{array}$ \\
\hline normal & 0.0495 & 0.5674 & 9.28 \\
\hline lognormal & 0.3870 & 0.5674 & 31.79 \\
\hline seragam & 0.4940 & 0.5674 & 12.93 \\
\hline
\end{tabular}




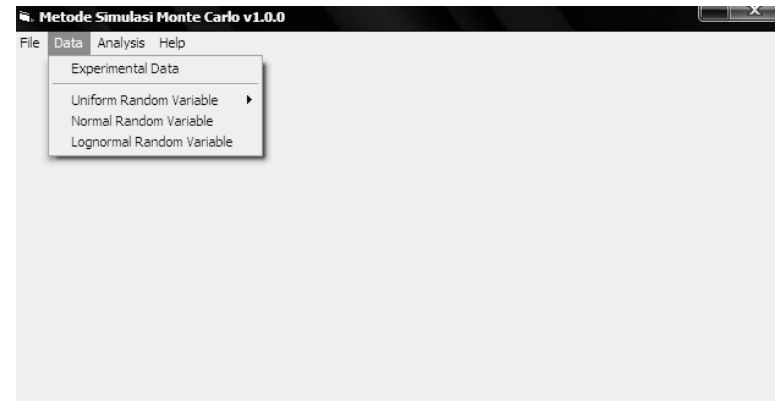

Figure 4. Monte carlo simulation software.

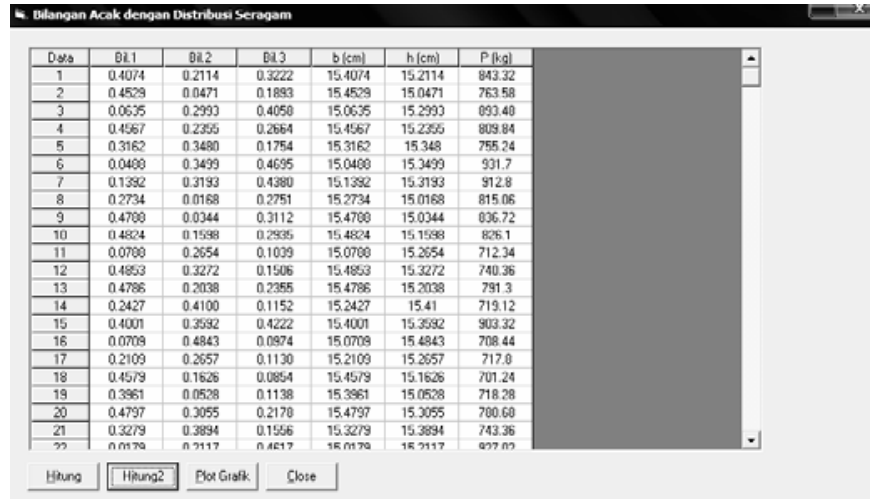

Figure 5. Uniform random variables for length, width, and load parameters.

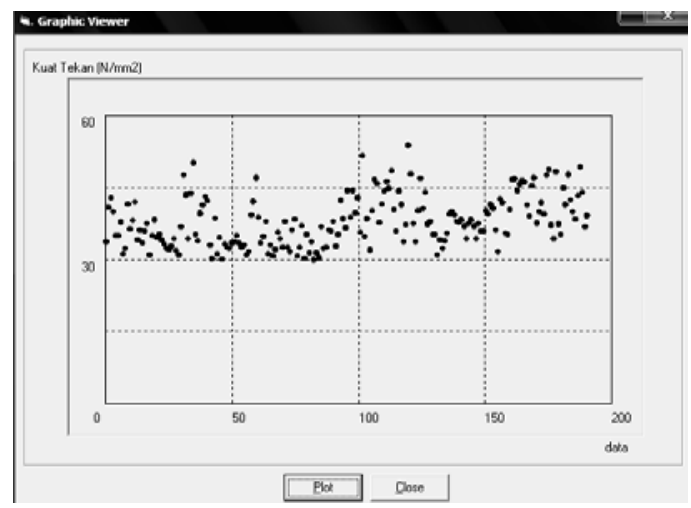

Figure 6. Graphic viewers.

\section{CONCLUSION}

The general conclusion for this study are:

1. Difference between monte carlo using normal random and uniform variables and experimental (using Grandt's equation) are less than 12.93\%, giving results which are much the same.

2. For overalls, results in this research indicate that Monte Carlo simulation technique is reasonable used to predict the reliability of the specific gravity of hardwood. 


\section{REFERENCES}

1. American Society for Testing and Materials (2002). Standard Test Methods for Small Clear Specimens of Timber, ASTM Standard D143-94, Annual Book of ASTM Standards v4.10, American Society for Testing and Materials, Philadelphia, PA.

2. Broek, D. (1982). Elementary Engineering Fracture Mechanics, Martinus Nijhoff Publishers, The Hague/Boston/London.

3. Forest Products Laboratory (1999). Wood Handbook Wood As An Engineering Material, General Technical Report FPL-GTR-113, Forest Products Laboratory, United States Departments of Agriculture.

4. Grandt, Jr., A.F. (2004). Fundamental of Structural Integrity, John Wiley \& Sons, Inc.

5. Microsoft Corp. (2007). MSDN Library for Microsoft VisualBasic 6.0, Microsoft Corp.

6. Mirzaei, M. (2006). Fracture Mechanics - Lecturer Notes, Department of Mechanical Engineering, TMU, url: http://www.modares.ac.ir, April 2008.

7. Nowak, A.S., Collins, K.R. (2000). Reliability of Structures, McGraw-Hill.

8. Pranata, Y.A. (2008). Studi Perbandingan Kuat Fracture Material Ortotropik dari Uji Eksperimental dengan Analisis Metode Elemen Hingga - Seminar Bidang Kajian 2. Program Doktor Ilmu Teknik Sipil, Universitas Parahyangan, Bandung.

9. Saouma, V.E. (2000). Lecture Notes in: Fracture Mechanics, Department of Civil Engineering and Architectural Engineering University of Colorado, Boulder, CO 80309-0428.

10. Smith, I., Landis, E., Gong, M. (2003). Fracture and Fatigue in Wood, John Wiley \& Sons, Inc.

11. Todinov, M. (2005). Reliability and Risk Models, Wiley.

12. Wikipedia (2008). Monte Carlo Simulation, Online Encyclopedia. 